\title{
EXPLORING COMPLEXITIES: MULTIRACIAL BLACK WOMEN - RACISM, SEXISM AND RESISTANCE
}

by

Shala N. Symonds, BSW. Ryerson University, 2016

\author{
An MRP \\ presented to Ryerson University \\ in partial fulfillment of the \\ requirements for the degree of \\ Master of Social Work \\ in the Program of \\ Social Work
}

Toronto, Ontario, Canada, 2017

(C) Shala N. Symonds 2017 


\section{AUTHOR'S DECLARATION FOR ELECTRONIC SUBMISSION OF A MRP}

I hereby declare that I am the sole author of this MRP. This is a true copy of the MRP, including any required final revisions.

I authorize Ryerson University to lend this MRP to other institutions or individuals for the purpose of scholarly research

I further authorize Ryerson University to reproduce this MRP by photocopying or by other means, in total or in part, at the request of other institutions or individuals for the purpose of scholarly research.

I understand that my MRP may be made electronically available to the public. 


\author{
ABSTRACT \\ Exploring Complexities: Multiracial Black Women - Racism, Sexism and Resistance \\ Master of Social Work, 2017 \\ Shala Nakaw Symonds \\ Masters of Social Work, \\ Ryerson University
}

This Major Research Paper (MRP) is a qualitative research study which features the narratives of two afro-Canadian women. My aim was to explore the unique experiences of racism and sexism experienced by mixedrace individuals. The research question asks: how do multiracial black women experience, understand, and resist anti-black racism and sexism? Critical Race Feminism (CRF) is the theoretical framework used to analyse participant narratives. This study uses phenomenology as a research method; data is collected through two semi-structured interviews. Five primary themes arose during the interviews: including a) racial identity; b) racism and microaggressions; c) sexism and patriarchal culture; d) internalized racism; and e) self-preservation and resilience. The findings revealed that racial identity development is a subjective, discursive, and complex process that is influenced by community and culture and racialization. Participants' narratives revealed that experiences with racism frequently take form in subtle yet impactful microaggressions. Sexist microaggressions and patriarchal workplace culture were identified as sources of gender-based marginalization promoting invisibility. Findings revealed that internalized racism is a psychological consequence of subconsciously indoctrinating racist discourse. Self-reflection, dialogue, and community building were revealed to be useful methods for multiracial black women's self-preservation and remaining resilient in a patriarchal white supremacist settler society.

Keywords: race, racism, anti-black racism, sexism, microaggression, identity, multiracial, Canada 


\section{ACKNOWLEDGEMENTS}

I want to thank Dr. Gordon Pon for being so supportive and encouraging throughout this process. I'm grateful to have been your student.

I also want to thank my participants for opening up their lives to me...

And finally I must thank my family; words cannot describe what your love and support has meant to me throughout this challenging process. 


\section{TABLE OF CONTENTS}

Introduction

Page \#1

Chapter 2: Literature Review

Page \#2

Chapter 3: Theoretical Framework

Page \#9

Chapter 4: Methodology

Page \#13

Chapter 5: Findings

Page \#16

Chapter 6: Analysis

Page \#30

Conclusion

Page \#38

Reference List

Page \#52 


\section{LIST OF APPENDICES}

Appendix A - Participant Consent Form

Page \#40

Appendix B - Interview Guide

Page \#43

Appendix C - Recruitment Script

Page \#45 


\section{CHAPTER 1. INTRODUCTION}

This study explores the realities of racism and sexism in the lives of multiracial black Canadian women. The research question asks: how do multiracial black women experience, understand, and resist anti-black racism and sexism? Critical Race Feminism (CRF) is the theoretical framework used to analyse participant narratives. This study uses phenomenology as a research method; data is collected through two semi-structured interviews. Five primary themes arose during the interviews: including a) racial identity; b) racism and microaggressions; c) sexism and patriarchal culture; d) internalized racism; and e) selfpreservation and resilience.

The subject matter in this MRP arose from my own practice of critical self-reflection and ongoing decolonization work. After reading the works of bell hooks, Frantz Fanon, Audre Lorde, and others, I developed a greater critical awareness of my own complicity in colonial, patriarchal and white supremacist discourse. Renowned black feminist scholar, bell hooks (1992), states that a crucial step in decolonization is breaking from hegemonic ways of seeing, thinking, and being that inhibit black folks' possibilities for imagining oppositional emancipatory narratives. From this I understood that in order to further decolonize myself, I would need to start by confronting the fact that I had internalized some racist and sexist discourse. The next step was to unlearn those ideas in order to reimage more empowering and liberatory possibilities. This decolonization work lead me to develop a critical inquiry into the phenomena that contributed to sustaining internalized oppression. It also fuelled my interest in how other racialized women, who are socially and ethnically positioned similar to myself, create and sustain selfempowerment and self-love. From this inquiry, my research questions became: how do multiracial black Canadian women experience and understand their experiences with racism and sexism? What do they do to combat those experiences to ultimately promote a loving, compassionate, empowered and liberated sense of self. In an effort to enact Critical Race Feminism (CRF) praxis, explored in greater depth in chapter 3, this MRP centers the narratives of racialized women. 


\section{CHAPTER 2. LITERATURE REVIEW}

\section{Racial Identity}

Forsyth and Carter (2012) define racial identity as the psychological meanings one makes of their racial group membership; this includes how one chooses to identify with emotional, behavioural, and cognitive expressions of their particular racial reference group. Identity can be a fluid and complex conception for individuals that are the product of multi-racial/ interracial unions (Siddiqui, 2011). According to Siddiqui (2011), multiracial individuals are positioned uniquely along the borders of singular racial categories. Multi-racial individuals can experience exclusion, privilege and identity denial in complex ways (Siddiqui, 2011). One privilege might include the ability to have options for selfdefinition or racial self-identification. An example of having 'options' for self-definition includes the notion of 'passing', in which individuals are able to visibly 'pass' as another more socially-profitable racial category (Siddiqui, 2011). Passing has important historical and contextual implications that are not explored in this study.

Identity development and formation can take various approaches for multiracial individuals as a result of identifying with one, both, or neither of their ethno-racial heritages (Lusk et al., 2011). Multiracial individuals commonly experience a negotiation between their own personal self-identification and the racial categories made available to them within specific social processes of racialization (Siddiqui, 2011). According to Rockquemore (as cited in Coleman \& Carter, 2007), there are four particular pathways for self-identification that mixed-race individuals commonly experience. Firstly, there is the ‘singular identity’, which describes individuals who identify mono-racially (i.e. black, white, etc.). Secondly, the 'border identity' describes individuals who identify as being of multiple racial categories, like mixed-race or biracial, etc. Thirdly, the 'protean identity' describes the shifting of identities according to the situation; this might look like someone who sees herself as mixed-race in their home, amongst their family, but black when outside of the home in a broader societal context. Lastly, the 
'transcendent identity' describes folks who view themselves as 'raceless' or post-racial (Coleman \& Carter, 2007).

\section{'Fitting in' - Social Repercussions}

There are often particular challenges and social repercussions for multiracial individuals who chose to assert or 'own' both of their racial heritages. These challenges can be especially poignant when the individual's racial backgrounds are socially positioned differently (Siddiqui, 2011). Some of these particular challenges include rejection or doubt from others when asserting their racial self-identification (Siddiqui, 2011). Being misrecognized is a common experience for multiracial individuals. Bettez (2010) found that identity for mixed-race women was further complicated by social repercussions; being perceived as a traitor to either side of their families for choosing a particular identity that veers from the dominant norm is one such consequence.

\section{Collective Racial Identity \& Belonging}

According to Lusk, Taylor, Nanney, and Austin (2011), creating a sense of racial belonging involves the conscious or subconscious incorporation of culturally based messages about a larger ethnic group into the individual's personal sense of self. Bettez (2010) found that racial identities are created discursively. As such, many mixed-race individuals experience racial identity formation based on their experiences with belonging and exclusion from ethnic groups (Bettez, 2010). Lusk et al. (2010) found that multiracial individuals who possessed a strong sense of group racial identity, felt a protective buffer to negative self-esteem during exposure to racism. Further linkages between self-perceptions and racism will be explored in the 'internalized racism' section of this literature review.

\section{Exoticization}

Women of multi-racial heritage have been historically framed and characterized as exotic (Root, 2004). The term exotic generally means to be of foreign origin, to be strange or unusual, or of unique/ experimental nature (dictionary.com, 2017). Studies have shown that multi-racial women, who lack a substantial visible cohort, experience self-consciousness about their physical appearance and a hyperawareness of being watched and evaluated by others (Root, 2004). Being exotic typically has a coded 
objectifying and sexual connotations (Root, 2004). Root (2004) asserts that the most frequent bio-psycho profile of mixed-race women is the stereotype that they are sexually promiscuous, immoral, passionate, and wild. Historically, 'mulatto' women whether enslaved or free, were regarded as being sexually desirable by virtue of their unique approximation to whiteness and blackness (Tate, 2007). Contemporarily, in part due to globalization, certain mix-raced bodies are viewed as 'super citizens', reflecting the promise of a new global order or a 'post-racial' world (Siddiqui, 2011). According to Haritaworn (2007, as cited in Siddiqui, 2011) multiracial individuals who are part white, have more access to celebratory exoticization, compared to their counterparts who are non-white or 'dually minoritized'. Contemporary discourses of exoticism still largely rely on racial hierarchies and biological determinism (Siddiqui, 2011).

\section{Racism}

Racism has a complex legacy and manifests in a multitude of subtle and overt forms (Giroux, 2003). Older notions of racism are made anew through continuous evolution. 'New racism' is expressed through dominant popular culture, education, geography, politics, economics, and various other institutions; it now operates in more covert forms (Giroux, 2003). The most commonly accepted concept of racism is one that refers to individual expressions of overt feelings or actions (Henry \& Tator, 2010). Racism, however, manifests itself not only within individuals, but also through groups, organizations and institutions; in each arena racism assumes a different form (Henry \& Tator, 2010). Racism is commonly ignored, denied, and/or regulated through privatized discourses that minimize racism to individual prejudices and psychological dispositions (Giroux, 2003). In minimizing racism to personal prejudice, governments contribute to the progression of systemic racism (Giroux, 2003). Instead of being conceptualized as a force for domination, exclusion and discrimination, race and racism become regulated as threats to status quo culture and are thus confined to the private sphere (Giroux, 2003; Pon, 2009). Denial is used as a powerful tool for rewriting the discourse of race. Although many individuals experience the detrimental impacts of racism, race discourses steeped in denial, serve to further 
marginalize its effects from the dominant public psyche and allow its impacts to flourish all the more insidiously (Giroux, 2003).

\section{Stereotypes}

The following will discuss each stereotype in greater detail.

Jezebel. Jezebel is a socially constructed stereotype figure that is projected onto black women who are perceived to be lustful, immoral, and sexually available. Historically, the Jezebel "was a powerful rationalization for the sexual atrocities perpetrated against enslaved African women. This image was necessary in order to justify the rape and forced breeding of Black women" (Donovan \& Williams, 2002, p. 98). This Jezebel stereotype is pervasive in the public psyche; the image of a 'wild', sexy black woman is continually reimagined in popular culture, music, magazines, pornography, etc. (Donovan \& Williams, 2002).

\section{Beauty}

According to Tate (2007), black women experience social pressure to modify their aesthetic appearance to that of European beauty standards. The notions of having 'good hair', or a 'good nose', and/or 'good complexion' are referencing this racist discourse, in which white physical features are deemed supreme. Thus, the pressure that black women feel is reflective of the dominant beauty paradigm that is inherently sexist and anti-black. Using white women as the standard by which all others are measured is an ideological practice with deep roots. Historically, European ideals informing beauty were constructed based on dominant patriarchal societal values such as modesty, purity, and fragility (Tate, 2007). Racist ideology constructed black women as the polar opposite to white women; while white women were symbolic of beauty embodied, black women were characterized as strong and immodest (Tate, 2007). Historically, one's physical traits such as hair texture, skin colour, and facial features had the power to drastically shape a black woman's quality of life. Contemporarily, black women continue to face perceptions and judgments of their desirability, femininity, and beauty that are rooted in anti-black sentiments (Tate, 2007). Within the dominant beauty paradigm, blackness is equated with badness. Statements such as, 'she's pretty for a dark-skin girl' are commonly made contemporarily (Tate, 2007). 


\section{Internalized Racism}

Racism exerts influence on both sociopolitical and personal levels. It can manifest in external forms through discrimination, harassment, prejudice, etc., and through internal means (Szymanski \& Gupta, 2009). Internalized racism (IR) is also known as 'internalized racial oppression', 'self-hatred', 'mental colonization', 'internalized white supremacy', etc. (Pyke, 2010). IR is the subconscious inculcation of racist ideologies about one's racial group (Pyke, 2010). It involves the acceptance of a racial hierarchy, as well as an ignorance or rejection of Indigenous/ African worldviews and cultural motifs (Bailey et al., 2011; Kohli, 2014; Szymanski \& Gupta, 2009; Szymanski \& Stewart, 2010).

Studies reveal that any racialized person who has been exposed to colonization and/or white supremacy can be impacted by IR; the phenomenon originates in cumulative exposure to racism (Kohli, 2014). According to Bailey et al. (2011)), white supremacy is the dominant mechanism of social control that constructs and reifies a racial hierarchy. Within this dominant framework, blackness and Indigeneity are depicted through racist doctrines, stereotypes, distorted and erased historical facts, and hatred (Bailey et al., 2011). IR is a logical repercussion for racialized folks who were reared within this dominant ideology. IR is not a result of some biological or cultural characteristic, nor is it a sign of weakness, inferiority, or a psychological defect (Pyke, 2010). Although experiences and awareness of IR varies for racialized individuals, it typically manifests through feelings of shame, lack of pride in one's race, dissatisfaction with one's biological traits, and a personal sense of inferiority (Bailey et al., 2011; Kohli, 2014; Szymanski \& Gupta, 2009; Szymanski \& Stewart, 2010).

Studies have shown that IR can be linked to the trauma of racial oppression/ racism (Watt-Jones, 2002). According to Watts-Jones (2002), although racialized folks may socially, politically and institutionally reject racism, they still, nonetheless internalize racism to varying degrees. IR is a multilayered, multi-dimensional phenomenon (Pyke, 2010; Watts-Jones, 2002). IR is not something that can be understood through binary oppositions or as either/or terms. Rather, IR should be conceptualized as something that is experienced on a continuum basis, through diverse experiences of exposures to racial 
oppression (Bailey et al., 2011; Kohli, 2014). IR is not a unitary or fixed experience, it assumes many forms across various situational contexts and intersectional systems of domination (Pyke, 2010).

Unlearning Internalized Racism. Studies show that IR is a common experience for many racialized women (Kohli, 2014). Consistently enduring racial slurs, mistreatment, questioning and scrutiny (especially when holding positions of authority), and being overlooked are common experiences for racialized women (Kohli, 2014). Because IR is typically accompanied by feelings of 'bottled up' shame or guilt, some women find it supportive and healing to discuss IR openly with others (Kohli, 2014). Guided dialogue can be used as a supportive strategy for unlearning racism. Kohli (2014) found that helping women develop a more critical understanding of IR as a product of racism is useful for alleviating women's feelings of shame and guilt. Anti-racism and feminist activism, social support, involvement in religious communities and spirituality are all potential moderators of the pangs of IR as well (Szymanski \& Stewart, 2010).

Critiques of Internalized Racism. IR assumes that racialized individuals are inherently complicit in their own domination (Bailey et al., 2011). Szymanski and Stewart (2010) assert that the notion of IR is pathologizing because it essentially 'blames the victim' and focuses primarily on their doings. Frosh (2013) cautions that psychological discourses on racism can be harmful because they perpetuate aspects of colonial culture through constructing a victimized social subject. Critics of IR remind researchers that theorizing IR should remain in the context of enduring oppression; the locus of analysis needs to remain within broad, social, cultural, and political contexts of racism, rather than the individual (Szymanski \& Stewart, 2010).

\section{My Study's Contribution to the Literature}

With this MRP, I explored how racism and sexism land uniquely on the bodies of multiracial black women. The literature has shown that IR is an unconscious by-product of racism that has detrimental psychological consequences (Fanon, 2008; Pyke, 2010; hooks, 1981; Watts-Jones, 2002). The literature also explores how racialized women experience, understand and unlearn IR (Kohli, 2014; 
Szymanski \& Stewart, 2010). Through this study, explore how being multiracial and/or being reared in predominantly white spaces, might further complicate experiences with IR.

Contemporary literature on multiracial women highlights various challenges to racial identity development (Bettez, 2010; Lusk et al., 2010). Literature also suggests that due to a long history of racism and sexism, multiracial women are at particular risk for being sexualized and exoticized (Donovan \& Williams, 2002; hooks, 1981; hooks, 1992; Root, 2004). Research has also shown that public discourse typically confines racism to the private sphere (Giroux, 2003). In this study, I am interested in exploring how experiences with racism might exacerbate or complicate feelings of isolation for multiracial black women. Ultimately, I aim to reveal how multiracial black Canadian women experience, understand and resist anti-black racism and sexism. This study will employ the narratives of two multiracial black Canadian women to fill a gap in research. 


\section{CHAPTER 3. THEORETICAL FRAMEWORKS}

My understanding of multiracial black Canadian women's experiences with gendered racialization has been informed by my own lived experiences, as well as Critical Race Feminism, Critical Race Theory, Anti-Racism, Feminism, Anti-Black Racism, Postcolonial, and Anti-Oppression scholarship. My exploration of multi-racial black women's experiences with racism and sexism are grounded in Critical Race Feminism (CRF) and Critical Race Theory (CRT). However, CRF largely provides the conceptual basis for my exploration of the social phenomena that impact my participants. Phenomena such as micro-aggressions, exoticization, invisibility, othering, etc. can all be further deconstructed with grounding in CRF. At the core of CRF lies a commitment to liberation, self-love, transparency, critical self-reflexivity, community building and social justice; these values are closely aligned with my own and are well-suited to this study

\section{Critical Race Feminism}

\section{CRF Epistemology}

CRF is a fairly recent framework that arose in part due to mainstream feminism's failure to thoroughly examine and challenge the role of white supremacy and colonialism in subordinating racialized women (Wing, 2003). CRF utilizes the theoretical foundations of critical legal theory and critical race theory to highlight the experiences of women of colour (Razack, Smith, \& Thobani, 2010; Wing, 2003). The concerns of heterosexual white men are continually prioritized, reinforced, and disseminated as neutral, normal, and ultimately true (Wing, 2003). Under this dominant paradigm, women of color are typically rendered invisible and voiceless (hooks, 1981; Wing, 2003). CRF challenges this by bolstering the concerns of racialized women while emphasizing the interlocking nature of social relations that impact women of colour in intersectional and compounding ways (Clarke, 2012; Crenshaw, 1991; Razack et al., 2010). CRF critiques the mainstream feminist notion of a unitary essential voice. According to CRF scholars, the essentialist feminist voice speaks primarily for middle and upper class white women (Razack et al., 2010; Wing, 2003). The intersections of race and gender identities must be thoroughly examined in order to grasp the anti-essentialist plight of racialized women (Wing, 2003). Although CRF 
allows for some essentialist constructs, such as referring to 'black women' as a group, CRF's foremothers acknowledge that the reality of any group is dynamic, complex and socially contextual (Wing, 2003).

CRF is essentially feminist anti-racism. CRF scholars and practitioners view both race and gender as social constructions that are deeply entrenched in vectors of power and oppression (Razack et al., 2010). CRF utilizes a critical emancipatory lens in posing fundamental inquiries into the perpetuation and magnification of gendered racialization. It interrogates the ways in which these dynamics are interconnected with colonialism and Indigenous dispossession within White settler nation-states (Razack et al., 2010).

\section{CRF Ontology \& Axiology}

CRF holds at its forefront a commitment to an anti-colonial praxis that aims to address continued colonialism and White supremacy in settler societies like Canada (Razack et al., 2010). CRF praxis is solution-oriented. Whether drafting legislation, supporting clients in direct-practice, joining practical coalitions, or mentoring students and youth, CRF praxis places racialized women at the center. Personal praxis is where CRF's axiology and ontology meet (Wing, 2003). CRF emphasizes the importance of providing racialized women the vision that they are valuable and worthy. Self-reflexivity and critical awareness of subject positioning are also fundamental to effective praxis (Pon, Gosine, \& Phillips, 2011). Ultimately, CRF principles derive from the struggle against racism and sexism to fight for dignity and liberation (Wing, 2003).

\section{Critical Race Theory}

\section{CRT Epistemology}

Critical Race Theory (CRT) views race as a complex and dynamic concept that continuously transforms under the pressure of social/political contestation (Calmore, 1995). Like CRF, CRT challenges the universality of white experiences, perceptions, and dominance. CRT problematizes whiteness as a force for domination that regulates, directs and controls normativity - the terms and conditions of acceptable behavior, thought, expression and performance (Calmore, 1995). Critical race scholars aim to 
reveal that racialized experiences are legitimate, appropriate and effective for analyzing and evaluating systems that promote racial subordination (Calmore, 1995). CR theorists view race and racism as defining feature of how North-American societies function (Evans-Winters \& Esposito, 2010). Race and racism are understood to be central, endemic, and permanent within societies dominated by white supremacy (Calmore, 1995; Evans-Winters \& Esposito, 2010). CR scholars challenge dominant ideologies and their various claims of race neutrality, color-blindness, meritocracy and equal opportunity (Evans-Winters \& Esposito, 2010).

\section{CRT Ontology \& Axiology}

CRT is activist in nature. It is grounded in a commitment to social justice and is typically interdisciplinary in scope and function (by necessity). CRT praxis centers the narratives of racialized, marginalized people (Evans-Winters \& Esposito, 2010). CRT values the ability to sustain authenticity in praxis. According to Calmore (1995), authenticity is required in order to connect with community-based social action, which is a component CRT praxis (Calmore, 1995). CRT scholars link authenticity with integrity, trustworthiness, and good faith; these are central values of CRT. Racialized peoples empowerment is of primary concern. CRT scholars aim to convey racialized peoples' knowledge in empowering ways. CRT practitioners ultimately strive for social transformation, dignity and self-respect.

\section{Anti-Racism}

Anti-Racism (AR) can be described as an action-oriented strategy that addresses and challenges the interlocking nature of oppression through systemic change (Dei, 1996, as cited in Pon et al., 2011). AR theorists identify the need for battling structural, cultural, economic, and internalized forms of racism (Dei, 1996, as cited in Pon et al., 2011). AR scholars view race as the primary prism through which to conceptualize and challenge interlocking systems of oppression. They stress the importance of recognizing race and difference within discourses of power and equity. They emphasize the importance of historical context of racism and colonialism in settler societies like Canada (Dei, 1996, as cited in Pon et al., 2011). The significance of self-reflexivity, whiteness, and white privilege are also emphasized in AR theory and practice (Pon et al., 2011). From an AR perspective, social justice entails struggling against 
both institutional and micro-level forms of racism to ultimately promote the equality and equity of racialized people (Pon et al., 2011).

\section{Anti-Black Racism}

Rooted in a history of colonialism and slavery, Anti-Black Racism (ABR) refers to specific forms of racism that are directed towards black people (Pon, et al., 2011). ABR manifests in all levels of society; criminal justice, health care, education, housing, employment and child welfare systems are all implicated (Benjamin, 2003, as cited in Pon et al., 2011). ABR is also a scholarly theoretical framework. ABR theory illuminates marginalization in specific laws and practices that result in racial disparities and disproportionalities for Black Canadians (James et al., 2010, as cited in Pon et al., 2011). ABR also refers to the constant resistance by black individuals and communities against this form of oppression (Pon et al., 2011). ABR is systematically sustained in society through White supremacy. White supremacy refers to the policies and practices in settler societies, the exaltation of white people as national subjects and the racializing and devaluing non-white 'others' (Thobani, 2007). White supremacy constructs non-white individuals and/or communities as threats to nation's security and prosperity (Thobani, 2007).

\section{Intersectionality}

Racialized women experience discrimination is unique ways; black women, for example, experience discrimination similarly to both black men and white women (Crenshaw, 1991). Intersectionality is term used to refer to the multiple and intersectional ways in which racialized women experience discrimination (Cho, Crenshaw, \& McCall, 2013; Crenshaw, 1991). It denotes the myriad of ways in which both race and gender interact to marginalize racialized women. Intersectionality "exposes how single-axis thinking undermines legal thinking, disciplinary knowledge production, and struggles for social justice" (Cho et al., 2013, p. 787). Intersectionality understands black women as vulnerable to 'double-discrimination' in which the combined impacts of both racism and sexism are felt (Crenshaw, 1991). When exploring the experiences of multi-racial black women, the need to account for multiple grounds of identity rather than using a singular focus is essential (Cho et al., 2013). 


\section{CHAPTER 4. METHODS}

In seeking to explore the realities of racism and sexism in the lives of multiracial black Canadian women, qualitative research appeared most fitting. Qualitative research is grounded in a curiosity and interest in how individuals construct their social worlds (Chase, 2003). Social justice interpretive frameworks, in qualitative research, provide an avenue for exploring specific conditions produced by systems that perpetuate exclusion and disadvantage (Chase, 2003). Fittingly, I am interested in identifying and further disentangling particular embodied experiences that materialize from systems like colonialism, patriarchy, white supremacy, hegemony, etc. A challenge of conducting qualitative research is participating in a form of social and human science that is not bound or guided by firm specific procedures (Chase, 2003). Part of the nature of qualitative inquiry involves the constant possibility of change and evolution; this complicates not only the progression of my study, but how it will be perceived upon completion as well (Chase, 2003). However, qualitative inquiry enables me the possibility of learning more about how multiracial black women experience, comprehend, and defend themselves in an endemically Eurocentric and male-centered society. Part of the beauty of engaging in qualitative inquiry is the evolution that takes place, not only in participants telling of experiences but in the researcher as well.

\section{Phenomenology}

Philosophical basis. Edmund Husserl is recognized as a pioneer in the more recent realms of philosophy and science. According to Moustakas (1994), Husserl is to credit for developing a system of philosophy grounded in 'subjective openness'. The term 'phenomenology' has documented use as early as 1765 (Moustakas, 1994). Phenomenology has been described as "knowledge as it appears to consciousness, the science of describing what one perceives, senses, and knows in one's immediate awareness and experience" (Moustakas, 1994, p. 25). Philosophers such as Husserl, Kant and Descartes understood knowledge to be rooted in intuition and essences that preceded empirical knowledge (Moustakas, 1994). Both Descartes and Husserl "recognized the crucial value of returning to the self to discover the nature and meaning of things as they appear and in their essence" (Moustakas, 1994, p. 26). 
Husserl believed that all scientific knowledge is rooted in inner evidence, and as inner evidence extends, so does the possibility of knowledge (Moustakas, 1994). The word phenomenon comes from the Greek word 'phaenesthai', which means to flare up, to reveal itself, or to appear (Moustakas, 1994). As such phenomenon means to place in brightness or to bring to light (Heidegger, 1977, as cited in Moustakas, 1994). A phenomenon can be described as something that appears in consciousness. In a broader sense of the word, phenomena provide the source for experience and thus the potential to generate new knowledge. Moustakas (1994) asserts that "phenomena are the building blocks for human science and the basis for all knowledge" (p. 27).

Research design. Phenomenology is a useful method for providing an in-depth understanding of a particular phenomenon as experienced by multiple individuals (Creswell, 2013). The ultimate goal of phenomenology is to enable the researcher the ability to describe the 'essence' of a particular phenomenon. Phenomenologists aim to describe what participants share commonly in their experiences of a phenomenon (Creswell, 2013). Phenomenology is my approach of choice because I aim to explore the essence of gendered racialization as experienced by multiracial black Canadian women.

Data collection. I collected data through conducting two, one-to-two hour semi-structured interviews with participants who identify with being multiracial black women, and have experiences with racism and/or sexism that they would like to share. An interview-guide was used to gear the interview process. I prefer interviewing to other forms of data-collection because I think it is important to give my participants the opportunity to share their experiences and confrontations with anti-black racism and sexism, and also have the space to speak to their strategies for resistance, dignity and ultimately survival. The interviews were audio-recorded for the purposes of post interview transcription, critical examination and in-depth content analysis. Creswell (2013) states that a key aspect of phenomenology is a philosophical discussion between the researcher and participants about the ideas surrounding the phenomenon. For me, this took place through a discussion that was held prior to the interview about what racism and sexism are and how these experiences can be uniquely complicated by identity, non-black parents, the absence of 'black community', etc. 
Recruitment \& confidentiality. For this study, I engaged multiracial black Canadian women to explore some particularly nuanced experiences involving in racism and sexism. Using convenience sampling, I recruited participants who are, like myself, from the west coast of Canada (British Columbia). I contacted women from among my network of contacts which I have developed over the course of my life. Once they confirmed their interest in the study, I obtained informed consent through emailing my consent form and the interview guide to the potential participants, remaining transparent and informative about the research process and their anticipated involvement. In the consent form (appendix A) I went into greater depth about confidentiality; participants were informed that their identities will be protected through assigning pseudonyms in the final research paper, as well as keeping their data stored in password protected devices that only I have access to.

Data analysis. Once the interviews have been completed I transcribed the audio recordings and began the process of forming codes and themes - the heart of qualitative data analysis (Creswell, 2013). Once the data was aggregated into smaller categories of information (coded), I worked to develop themes, reducing and/or combining codes so that I ended up with about four to six themes. The themes were organized into larger units of abstraction to convey larger meanings within the data (Creswell, 2013). My interpretation of the data was informed by my theoretical framework, which draws upon the scholarship of bell hooks, Kimberelé Crenshaw, Sherene Razack, and others. Once the data analysis was complete, I returned it to my participants for their review and approval. Finally, I wish to note that prior to commencing my data collection, my research proposal was approved by the Ryerson Research Ethics Board (REB). 


\section{CHAPTER 5. FINDINGS}

This chapter will discuss the narratives of two multiracial black women whose experiences took place in Hamilton, Ontario and in various cities in and around the Greater Vancouver Area, British Columbia. Pseudonyms have been assigned and some details of the participants' interviews have been excluded in an effort to protect their privacy. During the interviews, five central themes emerged which were the following: 1) racial identity; 2) racism and microaggressions; 3) sexism; 4) internalized racism; and 5) self-preservation.

\section{Racial Identity}

My interview questions began with racial identity. In my recruitment criteria, I was specifically looking to interview women who could identify with being both multiracial or biracial and black. I was interested in learning more about their racial identities and how having Canadian parents of differing ethnicities played into their individual understandings and experiences of self. Louise stated:

I consider myself biracial, mom white, dad black and some Aboriginal further back in our history. But growing up in Vancouver, I understand that people see me as black, and I've always had to explain who my mom is when we're out in a public setting or to my friends growing up. So I understand that generally people see me as black and I don't feel the need to correct them unless they're my friend; if we're close [then] they're going to know what I think but it doesn't bother me that the world sees me that way.

Although Louise self-identifies as bi-racial, she acknowledges that she is black, white, and Aboriginal. She also describes being aware that she is socially identified (or racialized) as black, and that she is okay with 'black' as her primary racial identifier. Lynn shared some similar sentiments, and further complicated the notion of racial identity:

I always saw myself as mixed or biracial, or something along those lines, but now I feel more comfortable saying that I'm also a black woman. I think that's because I learned some things to help me appreciate my blackness more. Now I still feel like I'm mixed but I also feel like I'm 
black, so both. [...] I don't fully identify with being 100\% black because I'm not, and I'm also not really accepted by people that would consider themselves black... So it's confusing because it's like you might identify some way and then you're not really included or accepted into any of those groups.

Here Lynn reveals some greater complexity of racial identity. In her statement, she indicates that her racial identity development is a dynamic process and that she has a growing appreciation for her blackness (racial pride). Lynn also talks about her 'blackness' in the form of a percentage in reference to her multi-ethnic genealogy and touches on community in racial identity.

\section{Community and Culture}

Louise explores the importance of community and culture on identity:

My father doesn't have any predominant culture from another country so there are many ways that I feel like I identify with Caucasian people's culture. [...] I think just overall not having a strong culture of my own that was distinct, and not being around [/] not having any other family aside for my immediate family to look to for community as well just made me feel very alone and isolated and always searching for my place in a group and not quite having that. [...] I think it's about not having your own kind around [;] you feel like an alien.

Here Louise revealed some of the nuanced experiences of being a multiracial black Canadian. She talked about how the absence of a racialized community or visible cohort, and a distinct culture create feelings of alienation and isolation. Lynn shared some of Louise's sentiments in stating:

I feel like for me as a mixed person with a predominately white family, dating a white boyfriend and everybody else is white, I'm in these white spaces and kind of stuck there dealing with the ignorance. Most of the full-black people I've known have a whole system of like--family and support.

Lynn revealed that the lack of a visible cohort/ racialized community impacts her as well. She communicated feeling 'stuck' in white spaces based on her surroundings with predominately white people 
and compares her experience to monoracial black individuals who she perceives as having more community and support than she experiences.

\section{Racism}

Participant narratives on racial identity and community progressed into discussions about overt and subtle forms of racism. Both Louise and Lynn shared compelling instances in which overt and micro forms of race-based aggression left them feeling disrespected and degraded. Louise began:

I had no peers that looked like me so I was made fun of [...]. [I] was made fun of as the new kid, I was made fun of for having short curly hair; people made fun of my complexion, so I felt like I bore the brunt of many racist jokes.

\section{Overt Racism}

Louise continues:

[A]s a child here I really strongly remember a [particular] experience: we had just moved to Richmond from Ontario; I was about nine years old and I made friends with a girl in my neighbourhood, a little Asian girl; and I remember us playing a couple times outside and then going to her house one time to ask her to play and I think her parent answered the door $[\ldots]$ it wasn't a friendly vibe that I was getting [...] and I asked can I come in and play and she said no you're not allowed in here. That was fairly blatant as a child, I wasn't allowed in her house. I thought it was because I was black, that's the impression I got; like I could play with her outside maybe, $[\ldots]$ but I couldn't go [in]to her house [...]. It made me feel dirty [...]. It made me feel like I [wasn't] human, like [I was] unworthy of friendship or kindness.

Louise also recalled:

I was spit on one time by some kids; they were riding by on their bikes when I was younger... it seemed intentional and that experience as well made me feel like wow... like I'm worse than dirt, people spit on the ground but you're going to spit at me and ride your bike and laugh...

Lynn also shared some of her more recent experiences with overt racism: 
Maybe about a year or so ago I was walking outside in downtown Port Coquitlam and some guy was mumbling under his breath behind me... [H]e said the N-word to me and then, I can't remember the exact sentence he used, but [it was] 'something, Nigger, something', and I was like okay, let me like quickly catch up to this group of young boys that were walking ahead of me, so I could feel a little bit safer, because he's following [me] and he kind of followed me for a bit, and it was really creepy.

Racist slurs have also been used against Louise in the recent past. She describes the impact of being called the N-Word at her workplace:

I've been called the N-Word several times, probably about four times in the last year-and-ahalf... It was hurtful but especially the context because I'm looking at these guys, a lot of them struggle with alcoholism or drug abuse, a lot of them are homeless and they're in our cell block because they've committed some sort of crime, they're having a hard time holding their own life situation together, you know. It's not a great place to be and yet they're able to look at me and use that language towards me; and initially the first time I heard it, I was angry with myself because I felt like wow you still have that on me though. You know? So I had to do a little bit of processing about that word and its power to me, and why and how to kind of deconstruct it and give it less power.

Both Louise and Lynn disclosed having various encounters with overtly racist individuals. This form of racial prejudice caused harmful impacts such as feelings of being degraded and unworthy of dignity, feeling devalued (like being 'dirty' or compared to dirt), feeling afraid and unsafe, as well as feeling powerless and insulted. Both participants also indicated acting or thinking strategically in order to alleviate some of the impacts. For example, Lynn walked quickly to catch up to another group ahead of her to create more safety, and Louise took some time to process and deconstruct the N-word in an attempt to give it less power.

\section{Micro-aggressions}


Another kind of race-based prejudice that was identified in the interviews is microaggressions. Microaggressions can be described as "brief and commonplace daily verbal, behavioral, or environmental indignities, whether intentional or unintentional, that communicate hostile, derogatory, or negative racial slights and insults toward people of color" (Wing Sue, Capodilupo, Torino, Bucceri, Holder, Nadal, \& Esquilin, 2007, p. 271). Two specific micro-aggressions came up in conversation with both Lynn and Louise: 1) being asked where they come from and, 2) being asked if the inquirer can touch their hair.

Where Are You From? Lynn re-enacts a dialogue in order to illustrate a typical form of microaggression that she endures:

[W] here are your parents from? Um they're from Canada. No, where are you from? I'm from Canada myself, thanks. Yeah but WHERE are you from?' like they're waiting for me to say Africa! Is that going to make you happy?

In Lynn's telling of that interaction, the inquirer emphasized the 'where' multiple times, which could imply that her first two answers would not suffice. Lynn continued:

[T] hat would be a common question throughout my life. Where are you from? And when I say Canada I get barriers or some sort of pushback like 'No! Where are you from?' [T]hat pisses me off, cuz I'm like bro, I'm more Canadian than you, so shut the f up. Not all Canadians are white, you guys immigrated here. And I'm part Native too so get the fuck out of here.

In recounting some of her experiences with micro-aggressions, Lynn was clearly frustrated. She described multiple experiences in which the inquirers were dissatisfied with Canada being her place of origin. Lynn hypothesized why that is:

I think that people think that Canadians are white people and so anyone that's not white can't be Canadian. And it's like stupid because no, you can't be Canadian either, you come from somewhere. White people weren’t just developed; they didn't just grow out of the grass. They came on a boat, just like everybody else. So it does annoy me when I get asked that question. The only people that seem to ask me that question are ignorant white people. Most of the time, it does 
annoy me because my grandparents are Canadian, and that's further back than most people's lineage in Canada.

She added:

Yea I have African ancestry and Aboriginal ancestry and Caucasian ancestry but I'm Canadian. Born here, my parents were born here, my grandparents were born here, everybody's here... I don't know what you want. They keep probing further and I'm like okay, 'Underground Railroad' from the States... Just like the Europeans came from Ireland or whatever. Do you know before Ireland where your people come from? Scandinavia? Are you a Viking? Did you know that?' I don't know, it's just annoying...

Lynn expressed having frequent experiences with being asked about her place of origin. She also mentioned that her grandparents were born in Canada and reiterated that she has Aboriginal ancestry. Evidently the 'where are you from' micro-aggression is a detrimental experience for multiracial black Canadian women like Lynn and Louise who have no recent immigration in their family and thus no other country to claim as home.

Touching Hair. Another micro-aggression that both Lynn and Louise talked about was related to their hair. Lynn gave the following example:

'Can I touch your hair?' that gets asked to me often and I'm finally starting to be like: Can I touch yours? Oh yours is so interesting! Like throw it back in their face... Like older crusty men, Caucasian men, like 'oh where do you come from? Oh, can I touch your hair?' Like shut up, get out of here, No!

Louise experienced similar encounters in her workplace:

[I]f it's a stranger, or not a stranger but an acquaintance, it's just rude... it's a boundary; am I asking to touch your hair? [I]t's just not appropriate and to have that done in a work setting, you know... Yeah it's happened twice, it's happened within the last year, and it's always usually by females, white females. 
Both Louise and Lynn specifically identify white people (Euro-Canadians) as the primary culprit of this type of microaggression. Lynn recounted a particularly invasive example:

$[\mathrm{T}]$ his time was when [my] girl's friend came up and grabbed my hair. Somebody was saying... 'oh she has curly hair, it's so nice' and then her white friend came over and grabbed my hair. Didn't even ask. Put her hand in my head and squeezed it, and I was like what the fuck? Like I wanted to punch her in the face.

Louise theorised:

I just think that because of the lack of understanding or exposure that a lot of people have, because [there's] not enough of us around, you just get a lot of dumb questions which make you feel separate and different from them which I believe is another form of ignorance related to racism; and it's very pervasive because it's subtle and is not steeped in hatred; it's steeped out of ignorance, so you run into it a lot but it still makes you feel like you're not part of the group, you know. $[\ldots][\mathrm{P}]$ eople want to touch your hair; this is not a petting zoo [...]. Just makes you feel like you're something different than everyone else.

Louise interprets these experiences as stemming from an ignorance that white individuals (the inquirers) have about black people. In her experience, she feels that the micro-aggressions do not come from a hateful place, however she nevertheless connects the ignorance to racism. The overarching sentiment conveyed by both Louise and Lynn is that the 'where are you from' and 'can I touch your hair' inquiries made them feel out of place, different, and exoticized.

\section{Sexism}

Both Lynn and Louise's shared their experiences with gender-based discrimination. During the interviews I was particularly curious about the connection between racism and sexism, and what are some of the unique or compounding experiences that multiracial black Canadian women might encounter.

\section{Invisibility}

Lynn described a sexist encounter that she experiences quite frequently: 
I feel like I experience that a lot where people come to talk to me and my boyfriend and they just make eye contact with him and talk to him. He's a white male by the way, so often times he's assumed to be the leader; he's assumed to be the one to talk to about things, where I'm just ignored, often. I'm used to it and it's so fucked up.

She continued:

I was actually pleasantly surprised when we went maybe two weeks ago to [David's] friend's BBQ, another white guy. [...] I was surprised that these guys included me in their conversation, because they were having a 'guys conversation'. How fucked up is that, that I'm surprised that these men are actually talking to me and looking at me and not just David or not excluding me from the conversation. So that's an example of the normalcy of I guess the misogyny or just the way that you know men will just communicate with each other and not include you.

Louise shared an example of a similar experience that took place at her work:

I remember working with this friend of mine $[\ldots]$ he was having an issue with his computer that I knew how to fix and we were sitting right beside each other and I watched him ask all these other people for help, like strangers around us for help and he didn't even ask me. [...] I thought to myself, I'm not even going to say anything unless you ask me cuz this is straight-up ridiculous.

Louise continued:

I don't know where that comes from; I don't know if that's because I'm a woman, if he just assumes that I might not know enough about computers, or because I'm black - maybe I know about rap but I don't know about computers. [...] I've definitely had that experience when you know something and you're saying it over and over again and people keep asking the question for someone else to say it.

Both Lynn and Louise expressed being overlooked and seemingly invisible during their encounters with men. Lynn expressed that these interactions are so commonplace for her that she's become accustomed to it and is surprised when men directly engage her while in the presence of her boyfriend. Louise's example 
was particularly poignant for her because it came from a friend and colleague of hers, whose actions could be perceived as indicating a lack of confidence in Louise's abilities.

\section{Patriarchal Workplace Culture}

Louise elaborated further on sexism in the context of her work:

It's definitely a sensitive topic within the context of policing because of the history but I can say that applying to be a part of that industry I was aware of the history so it's something that I was prepared for; I was prepared to work and to show my value through my productivity and the quality of my work.

Louise continues:

In terms of working in the industry and being female, I do feel a sense of pressure to be excellent. [...] If I make the same mistakes as Joe Blow, it's going to look worse on me or people might make assumptions about me that are different than if the average white dude made the same mistake. [...] I think even some of the skill sets that women bring, being strong communicators or more empathetic stereotypically, not across the board that's for sure, but those skills have not always been respected or embraced by the culture.

Here, Louise describes that she feels a great sense of pressure to be excellent at her work and that there is a particular history or culture in policing that undervalues women. Louise identified being aware of this culture prior to her entering the industry and thus prepared herself. Louise then shared a clear example of a gender-based/ sexist microaggression that she experienced at work:

[T]his was an isolated incident, it's definitely not across the board but around this concept of asking for backup to go to file [...] that I don't feel safe about [...]. This person who [was] kind of giving me flak for it was explaining how he deals with things, but this guy was 6'4 and like 250 pounds and the world reacts differently to him than they would to me, and I was new to the area, new to the job, and I just didn't feel that his advice was helpful. It made me feel tentative to ask for backup when I felt like I needed it and that's not safe in the work that we do. [...] [He] told me a story about an officer, a female officer [who] he worked with who was scared and didn't even 
get out of the car at a call that she went to because she heard that somebody was going to fight when they saw police officers, and he was asking me are you afraid? And I was thinking to myself first of all, my fear is none of your business [...] and you don't know how I react when I'm afraid. You don't know that I work through my fear and that I handle my fears and get the job done, and that I worked just as hard as you did to get this badge. So it's none of your business how I'm feeling right now. I just took offense to the whole conversation. [...] The experience he referenced, and asking me about my fear, and comparing me to another officer that he clearly didn't respect seems like a blow to being female on the job.

Louise provided a vivid example of the impact of sexist microaggressions. In the scenario detailed above, Louise's colleague was clearly passive aggressive in telling her about the other female officer whose fear prevented her from doing her job effectively. His advice to Louise was thoughtless and inconsiderate of her unique positionality in policing; it ultimately left her feeling disrespected and hesitant to call for backup in future which could compromise her safety.

\section{Internalized Racism \& Sexism}

In the next portion of my interviews I wanted to further disentangle the longer-term impacts of multiracial black women's frequent exposure to race and gender-based microaggressions. I was curious about internalized-oppression and the notion that racist and/or sexist discourse can be internalized. Louise shared a compelling example about the internalizing of racist ideals:

It's amazing how young they are when they start to show signs of self-hatred. You know I think my eldest was in kindergarten when she started to tell me that she didn't like her hair texture; she wanted it to be straight, so that when she shook her head 'no' that it would flow back and forth over her shoulders, which afros just don't do. And probably one of the worst comments she made was if she scratched her skin off, would it be white underneath... just wanting and longing to be like other people and not different, it was painful to see that in her.

Louise spoke about an important personal example of how her daughter had expressed wanting different hair texture and a different skin colour as early as five years old. This was a painful experience for Louise 
as she identified her daughter's thinking as self-hatred. Louise also talked about internalizing racist, sexist discourse in relation to her experiences at work:

I think the internalizing piece is just having that really high standard, and being in my mind, and being hard on myself, and wanting to be as perfect as possible, you know, so that I'm not giving people a reason to not respect me or not trust that I'm good, [that] I'm not going to do a great job as a woman and as a minority, I don't want to be that guy.

Here, Louise is talking about holding herself to a standard of excellence to combat racist and sexist perceptions that might assume less of her. She then went on to share an experience that took place during work that she related to internalized racism:

I think sometimes I feel embarrassed in general when I see other people of colour making mistakes or doing stereotypical things. I don't know if that fits into the internalized racism category, but I went to a call recently where the woman was Caucasian and disabled and married this man from the [United] States, a black American who brought his sons up from a different relationship. And the sons are causing problems for this woman and I had another partner there that was new to the area, and I just felt so embarrassed. Like this woman opened up her life to these kids and then they were taking advantage [of her] and being disrespectful. I just felt like we're not all like that; I just wanted her to know. And I think that's not healthy. And I don't know that everyone else does that, you know, when they see a white person on TV doing something undesirable [do] they feel embarrassed and have to explain to everyone? I don't think other people do that, but I definitely feel that way sometimes.

In this example, Louise describes feeling embarrassed when she witnesses black people behaving in ways that align with negative stereotypes about black people. For example, she expressed wanting the woman to know that not all black people are disrespectful or causing trouble. She also identifies that this thinking is problematic, or 'unhealthy' and connects it to internalizing racist discourse. Lynn also reflected on her experiences with internalized racism: 
I think racist wise, like comparing myself to a white beauty standard and never feeling that pretty. Not that I don't, I am confident, I just don't really give a fuck that's how I feel confident. But if I was to really be like 'am I so beautiful?'... Certain ideal beauty types, I've never felt like I fit into. [...] I get treated completely different than people that I think fit into that standard of beauty. Like Cara, for example, a beautiful friend of [mine]; she has a small nose, she dresses a certain way, she puts her makeup on a certain way, white women love that shit. [...] Sometimes I don't exist when I'm around her. Like they don't even serve me, they don't talk to me, they're so focused on her nails, they're so focused on her hair, so focused on her lashes, so focused on her clothes, they forget I exist so therefore, I don't feel like I have this beauty standard that people notice.

Here Lynn talks about the dominant beauty standard that places value on small noses, long hair, and a very particular feminine performance. Although Lynn expressed that she is confident in herself, based on witnessing the differences between how she and her friend (who fits into the dominant beauty ideal more readily) are treated, she believes that she is not 'that pretty'. Lynn connects this belief about herself to internalizing racism.

\section{Self-preservation}

I wanted to conclude the interviews by learning more about how my participants remained psychologically well and resilient amidst their relentless encounters with both racism and sexism. Louise talked about the mental processing that's involved in her resilience, and how thinking through her experiences gives her strength. She spoke specifically about how she manages with being called racist slurs on the job:

I had to somehow take the shame out of the [N-]word you know, and I took some time and thought about what our people have suffered through in slavery, how hard they worked and how resilient they were and things that I could be proud of out of that circumstance and that's what helped me to give the word less power, you know. It's just like yeah, and what? Those are my 
ancestors, what's your point. I think it's a work-in-progress too, I don't think it's a complete solution. I'll have to revisit that again, but it was a start, a positive start.

Louise identified that reflecting on the strength and resilience of her enslaved ancestors was helpful in alleviating the shame that the N-Word incites. She also talked about strategies she uses to support her children:

I'm so grateful that my kids have beautiful aunties of colour and uncles, people who are young and educated. I'm trying to basically have them aware of our history whether that's through literature appropriate for the kids, having them participate in cultural festivities around the city, is important to me... My husband is Jamaican, so being around other people of that culture whenever possible is important to me and having a lot of dialogue ultimately because I think it's multidimensional; it's not just race but it's also being a girl and having insecurities and just having to work through that; so I just try to have a lot of open dialogue about things that they're having difficulty with, whether it's her complexion whether she wishes that she was white; I find them pictures of beautiful women of colour as an example.

She continued:

[T] hey just have so much more access and exposure than I did and that already makes me feel hopeful; not only that but it's the people that they have in their life, they're surrounded by love. My mom is Caucasian and she loves them deeply, [they have] beautiful aunts and uncles to see young people who can help me set examples for them, it makes me think that they're on a better track than I was and have more of a sense of community with seeing people that look like them. Louise describes how having an open dialogue with her children about the challenges they face helps to buffer some of the racist and sexist discourses that they're exposed to. She is hopeful that her daughters will have a better experience than she did growing up because of their exposure to community and culture and access to examples of intelligent black women. Lynn also talked about the importance of dialogue as a strategy for coping: 
Talking about it helps me [and] venting about it. [...] [J]ust trying to prove people wrong ignites a fire. I think that's why a part of me wants to feel like I'm valuable, I'm respected, I'm successful. [...] I kind of want to prove people wrong and that kind of drives my fire for success.

Lynn describes using her experiences as fuel and motivation for being successful. She finds strength in proving people wrong and revealing to them that she is in fact valuable, respectable and successful.

Louise on the other hand takes solace in disregarding those individuals:

I just [have to] keep moving and luckily I have family and obligations and a great job to occupy my mind. [...] I just choose to focus on other things rather than stupid people...

This is my thing, I don't I want to give my power away right, so as much as possible I'm going to do everything that I can do to be positive and to control what I think about so that I can be happy ultimately; and I think [that] a lot of the things that you allow into your mind can dictate how you're going to feel, so a lot of that is a conscious choice for me.

Whether it's talking and venting, building community and engaging in culture, looking to positive examples, or mental processing and choosing what will be permitted to occupy their minds, both Louise and Lynn practice strategies for resilience that support their emotional and psychological wellness amidst their daily encounters with racism and sexism. 


\section{CHAPTER 6. ANALYSIS}

In this chapter I discuss the findings in relation to my theoretical framework of Critical Race Feminism (CRF). Based upon an analysis of the narratives of two multiracial black Canadian women, five themes were identified, which are: 1) racial identity; 2) racism and microaggressions; 3) sexism; 4) internalized racism; and 5) self-preservation. Critical race feminists note that both race and gender are understood and criticized as social constructions that are deeply entrenched in vectors of power and oppression (Wing, 2003). In being mindful of Anti-Racism (AR) praxis, I aim to emphasize the importance of the historical context of racism and colonialism in settler societies like Canada (Dei, 1996, as cited in Pon et al., 2011). The participant narratives clearly show how whiteness is a force for domination and this will problematized throughout this analysis (Calmore, 1995). Self-reflexivity is an important practice for CRF; I strive to practice self-reflexivity and attempted to invoke self-reflections with my participants during the interviews. Their personal narrations explored below, reveal a selfreflective process in which Lynn and Louise detail some of their daily lived-experiences with racism and sexism. From an AR perspective, social justice entails struggling against both institutional and microlevel forms of racism to ultimately promote the equality and equity of racialized people (Pon et al., 2011). This study has evolved fittingly for theorizing micro-level forms racism in greater depth.

\section{Racial Identity}

Siddiqui (2011) found that multiracial individuals commonly experience a negotiation between their own personal self-identification and the racial categories made available to them through processes of racialization (Siddiqui, 2011). Lynn and Louise expressed that they are both racialized mono-racially (black), although they self-identified as both black and biracial/ mixed-race. Lynn and Louise selfidentified in alignment with the 'border identity' describing individuals who identify as being multiple racial categories (i.e. black and white, multiracial, mixed, etc.) and the 'protean identity', which refers to

the shifting of identities according to the social context (i.e. seeing oneself as mixed-race in the home but black when outside of the home). Louise and Lynn also spoke about the lack of racialized/ black 
community and culture in their upbringings. In stating that her grandparents were born 'here' (Canada), Lynn indicated that she is at least fourth-generation Canadian on one side of her family (first generation being the individuals who immigrated to Canada). She also stated that she has Aboriginal and African ancestry - referencing folks who've been in North America for multiple generations. The participant narratives on identity were further revealing of the complexity of identity and reaffirming of the literature that describes race categories as dynamic social constructions.

\section{Community and Culture}

Bettez (2010) and Siddiqui (2011) state that multiracial individuals commonly experience racial identity formation guided by their experiences with belonging and exclusion from ethnic groups (Bettez, 2010; Siddiqui, 2011). They indicate that rejection from ethnic groups is a common experience for multiracial individuals (Bettez, 2010). Lynn expressed feeling exclusion from racial groups - identifying that she felt isolated and alienated in predominately white settings. She also stated that she has not always felt accepted by black folks. Louise also shared that she has very little black community or visible cohort outside of her immediate family and that she often felt singled out and isolated in her experiences with racism. One particularly relevant study, revealed that multiracial individuals who possessed a strong sense of group or communal identity, felt a protective buffer against negative self-esteem during exposure to racism (Lusk et al., 2010).

\section{Racism}

Critical Race (CRT) theorists and Critical Race feminists (CRF) understand race as a complex and dynamic constructs that continuously transforms under the pressure of social and political contestation (Calmore, 1995; Wing, 2003). Contemporary racism can be conceptualized as a result of Whiteness, a system that promotes and sustains white supremacy through policies, practices, and norms in settler societies that exalt white people as nationals, and create racialized 'others' of non-white individuals and groups (Thobani, 2007). CR theorists view race and racism as defining features of how North-American societies function (Evans-Winters \& Esposito, 2010). Race and racism are understood to be central, 
endemic, and permanent within societies dominated by white supremacy (Calmore, 1995; Evans-Winters \& Esposito, 2010).

Racism manifests itself not only within individuals, but also through groups, organizations and institutions; in each arena racism assumes a different form (Henry \& Tator, 2010). New or contemporary racism is often expressed through dominant popular culture, education, geography, politics, economics, and various other institutions in more covert forms, than they were previously (Giroux, 2003). In Canada, denial is used as a powerful tool for rewriting the discourse of race (Giroux, 2003; Henry \& Tator, 2010). Although many individuals experience the detrimental impacts of racism, race discourses steeped in denial, serve to erase from the dominant public psyche its deleterious impacts (Giroux, 2003). Rooted in a history of colonialism and slavery, anti-black racism (ABR) refers to the various forms of racism that are specifically directed towards black people (James et al., 2010, as cited in Pon et al., 2011).

\section{Micro-aggressions}

Microaggressions can be defined as "brief and commonplace daily verbal, behavioral, or environmental indignities, whether intentional or unintentional, that communicate hostile, derogatory, or negative racial slights and insults toward people of color" (Wing Sue et al., 2007, p. 271). Two primary micro-aggressions were identified in the interviews: 1) the participants being asked where they are from, and 2) the participants being asked if the inquirer could touch their hair. In the following few paragraphs, I aim to explore some theory that is indicative of the culture that breeds such encounters.

The Ontology of Forgetting. Lowe (1996, as cited in Pon et al., 2011) describes an ontology of forgetting in which nations like the United States and Canada 'forget' the genocide of Indigenous Peoples and their histories of colonialism, Western imperialism and white supremacy, that were foundational to the formation and development of such states (Baskin, 2006; Pon et al., 2011). This 'forgetting' enables nation-states like Canada to minimize its involvement in over two-hundred years of slavery (James et al., 2011, as cited in Pon et al., 2011). Both the British and French enslaved African Peoples in Canada (James et al., 2011, as cited in Pon et al., 2011). Lynn and Louise both indicated that their ancestors were 
enslaved African folks as well as Indigenous Peoples, and yet they are commonly asked about their place of origin. The ontology of forgetting helps to conceptualize this microaggression.

Exalted National Subject. The exalted national subject arises through settler societies, like Canada, whereby Europeans come to claim status as the national subject and all the entitlements of a nation (Thobani, 2007; Pon et al., 2011). The national subject is depicted as having to defend himself against the 'stranger'; the 'stranger' is often the racialized 'Other' - the refugee, immigrant, or Indigenous person who is casted in the trope of a concerning figure who wants what the nationals have (Thobani, 2007). The 'stranger', or racialized 'Other', is popularly depicted as a threat to the collective welfare and prosperity of the nation and as being devoid of the national's values and qualities (Thobani, 2007). The national subject is also institutionally and systematically reaffirmed. Their narrations are inscribed into state policies and procedures. For example, immigration policies have mirrored the national's aims in employing explicitly racist and sexist discourses to prevent non-white women from immigrating to Canada (Pon et al., 2011; Thobani, 2007). Under this prevailing discourse multiracial black Canadian women such as Lynn and Louise are viewed as alien to the state. Considering the discourse of the exalted national subject and the ontology of forgetting, white men who tend to inquire most frequently about Lynn and Louise's places of origin, would likely feel entitled to inquire about where they are from. However, it should be noted that the 'where are you from?' micro-aggression is a particularly thoughtless question posed towards individuals like Lynn and Louise who have no recent immigration in their families, and in fact, a history of forced migration, slavery, and genocide in North America.

Exoticization. During the interviews, exoticization arose as another phenomenon that has linkages to microaggressions, and racist and sexist discourses. In her interview, Louise stated: "People want to touch your hair, this is not a petting zoo..." (Louise, July 7th, 2017). According to the literature, women of multi-racial heritage have been historically framed and characterized as exotic, meaning to be of foreign origin, to be strange or unusual, or of unique experimental nature (dictionary.com, 2017; Root, 2004). Historically, 'mulatto' women whether enslaved or free, were regarded as sexually desirable by virtue of their unique approximation to whiteness and blackness (Tate, 2007). Studies show that a 
frequent bio-psycho profile of mixed-race women is the stereotype that they are sexually promiscuous, immoral, passionate, and wild (Root, 2004). Studies have also shown that multi-racial women, who lack a substantial visible cohort, experience a hyper-awareness of being watched and evaluated by others (Root, 2004). The scrutiny of black women's bodies and their hair has important historical implications that are not explored here, however, further implications on white standards of beauty are noted below. In their interviews, both Lynn and Louise expressed that the 'can I touch your hair?' and 'where are you from?' microaggressions left them feeling alienated, disrespected, and exoticized. As a multiracial black Canadian woman myself, I would personally identify these feelings as common during exposure to racism.

\section{Race \& Gender}

\section{Invisibility}

Critical race feminists are critical of the racial and gendered order that continually prioritizes, reinforces, and disseminates the concerns of heterosexual white men (Wing, 2003). Under this dominant paradigm, women of color are typically rendered invisible and voiceless (hooks, 1981; Wing, 2003). In her reflections on sexism, Lynn stated:

I feel like I experience that a lot where people come to talk to me and my boyfriend and they just make eye contact with him and talk to him. He's a white male by the way, so often times, [...] he's assumed to be the leader, he's assumed to be the one to talk to about things, where I'm just ignored, often.

Lynn's experience provides a concrete example of the ways in which racialized women are unseen and undervalued in patriarchal culture. In her interview, Louise also identified being overlooked and seemingly invisible during some interactions with colleagues. Louise spoke about a particular history and culture in policing that would likely impact her in unique ways as a racialized woman. Louise stated that she feels pressure to be excellent and that her mistakes carry different implications than white men. Research reveals that racialized women in position of authority commonly endure racial slurs, mistreatment, questioning, scrutiny and being overlooked (Kohli, 2014). Louise provided various 
examples being overlooked and experiencing gender-based microaggressions on the job. The literature reveals that racialized women experience discrimination in unique ways. Black women, for example, experience discrimination similarly to both black men and white women. Black women are thus vulnerable to 'double-discrimination' in which the combined impacts of both racism and sexism are felt (Crenshaw, 1991).

\section{Internalized-Oppression}

\section{Internalized-racism}

During her interview, Louise spoke about an important personal example of internalized racism (IR). Louise shared that her daughter expressed wanting to have different hair texture and skin colour, and that she wanted know what would happen if she scratched her brown skin off... Louise described this incident as a painful experience for her to witness and identified her daughter's rhetoric as self-hatred. The literature describes internalized-racism (IR) as the subconscious inculcation of racist ideologies about one's racial group (Pyke, 2010). Although experiences and awareness of IR varies for individuals, it typically involves feelings of shame, lack of pride in one's race, dissatisfaction with one's biological traits, and a personal sense of inferiority (Bailey et al., 2011; Kohli, 2014; Szymanski \& Gupta, 2009; Szymanski \& Stewart, 2010).

Internalized racism can impact any racialized person who has been exposed to colonization and/or white supremacy; the phenomenon originates in cumulative exposure to racism (Kohli, 2014). Internalized racism is a logical repercussion for racialized folks who are reared within colonial settlersocieties like Canada. IR is not a result of biological or cultural characteristics, nor is it a sign of weakness, inferiority, or a psychological defect (Pyke, 2010). bell hooks (1992) theorizes that when black people look at the world and themselves through a lens of White supremacy they are internalizing racism (hooks, 1992).

Beauty Implications. The participant interviews revealed that IR has beauty implications as well. Lynn described comparing herself to white beauty standards and feeling as though she was not 'that pretty' because of her inability to mimic them. The literature reveals that black women experience social 
pressure to modify their aesthetic appearance to that of European beauty standards. The notion of having 'good hair', or a 'good nose', and/or 'good complexion' is referencing racist and anti-black discourse in which blackness is equated with badness and white physical features are deemed supreme (Tate, 2007). The pressure that black women feel is reflective of the dominant beauty paradigm that is inherently sexist and anti-black (Tate, 2007). Contemporarily, black women continue to face perceptions and judgments of their desirability, femininity, and beauty that are rooted in anti-black sentiments (Tate, 2007).

\section{Self-preservation/ Resilience}

Critical race feminism principles emphasize the importance of providing racialized women the vision that they are valuable and worthy. With this in mind, I wanted to conclude my interviews with inquiring about the ways in which Lynn and Louise remain psychologically and emotionally well. Research and participant narratives revealed that enduring constant racist and sexist microaggressions takes an emotional and psychological toll (Kohli, 2014, Pyke, 2010, Root, 2004; Tate, 2007; Wing Sue et al., 2007). During the identity portion of her interview, Lynn revealed that she learned some things that have helped her 'appreciate her blackness' more and thus develop a greater sense of racial pride. Kohli (2014) found that helping women develop a more critical understanding of IR as a product of a systemic racism is effective for reducing negative self-perceptions. AR and feminist activism have also been identified as moderators to some of the mental and emotional consequences of IR (Szymanski \& Stewart, 2010). Louise spoke about the importance of mental processing to combat her experiences with discrimination. She identified that self-reflecting on the strength and resilience of her ancestors, helped her to decrease the power of racist slurs. Considering historical context is a fundamental aspect of CRF and AR theory and praxis, it appears to be supportive for multiracial black Canadian women as well (Szymanski \& Stewart, 2010; Wing, 2003).

Szymanski and Stewart (2010) contend that guided dialogue is another tool for assisting women in processing and unlearning racism (Szymanski \& Stewart, 2010; Watts-Jones, 2002). Both Louise and Lynn identified dialogue or venting as strategies that they use to maintain their wellness. The denial and privatization of racism discourse contributes to isolating feelings that Louise and Lynn expressed 
experiencing (Giroux, 2003). The literature states that fostering a sense of community is supportive practice for racialized women (hooks, 1992; Watts-Jones, 2002). Louise spoke about creating a sense of community and culture for her daughters to support them with self-love. Evans-Winters and Esposito (2010) found that young black women were most resilient when their families taught them about race, class, and gender oppression and when they participated in family discussions about how to combat racist, classist and sexist forces. Young black girls were most resilient when they received family and community support simultaneously (Evans-Winters \& Esposito, 2010). Based on the literature, engaging in education, activism, self-reflection, guided dialogue, and fostering community are all supportive strategies for dealing with racist and sexist microaggressions.

\section{Implications}

It is important to note that generalizability of findings was not sought in this MRP; rather consistent with CRF praxis, I sought to value and affirm the individual voices and lived experiences of racialized women (Wing, 2003). However, due to the number of research participants, the study findings are not generalizable which could be considered a limitation of this study. Future studies could involve examining, in greater detail, mixed race women with Aboriginal ancestry; this was briefly touched on is this MRP, however, it could be the subject of future studies.

My study reveals the important insights that mixed race black women can contribute to anti-racism scholarship. The stories shared by the two women who participated in this study demonstrate that they occupy social locations that bring to bear very unique experiences of racism and sexism. By complicating the subjectivity of individuals beyond rigid racial categories, these two women reveal the tremendous resilience and epistemological acumen that they possess, which permits them to navigate and resist daily racial microaggressions in a settler society such as Canada. The implications for researchers is that research study designs should be conceptualized with an inclusive and deliberate aim to involve individuals who self-identify as mixed race. 


\section{CHAPTER 7. CONCLUSION}

With a grounding in CRF theory and praxis, this study sought to explore multiracial black Canadian women's lived experiences with racism and sexism. My initial research question was: how do multiracial black women experience, understand, and resist anti-black racism and sexism? In alignment with CRF praxis, this MRP utilized and bolstered racialized women's voices to convey their knowledge and affirm their experiences to ultimately emphasize their humanity and dignity.

Qualitative research methodology, phenomenology in particular, was used to gain an in-depth understanding of a particular phenomena as experienced by multiple individuals (Creswell, 2013). Phenomenologists aim to describe what participants share commonly in their experiences of a phenomenon (Creswell, 2013). This research method enabled me to describe the essence of multiracial black Canadian women's experiences with identity, racism and sexism. Two, one-to-two hour, semistructured interviews were conducted as my method of data collection. Eligible participants were women who self-identified with being multiracial and black and had experiences with racism and/or sexism that they'd like to share. The interviews were audio recorded, transcribed, coded and thematically aggregated.

Five primary themes arose from the interviews: 1) racial identity; 2) racism and microaggressions; 3) sexism; 4) internalized racism; and 5) self-preservation. The findings revealed that racial identity development is a complex and subjective phenomenon that is formed discursively through inclusion and exclusion from groups and is influenced by processes of racialization, othering, community and culture. The findings also revealed that the impacts of continuous race-based microaggressions in conjunction with having a lack of black community or visible cohort, lead to harmful experiences of isolation and alienation. Findings regarding sexism revealed that the impact of sexist microaggressions and patriarchal culture is invisibility and a lurking sense of hyper-scrutiny for racialized women. Participants identified striving for perfection a remedial practice to ultimately combat racist and/or sexist perceptions.

Findings surrounding internalized racism (IR), revealed that internalizing racist discourse about oneself and others, is a lived experience of some multiracial black Canadian women. IR was identified as 
a psychological consequence of dwelling within a white supremacist settler society like Canada (Fanon, 2008). Findings also revealed that talking about their lived experiences with racism and sexism is essential for participants' psychological and emotional wellness. Self-preservation and resilience was identified as being garnished ultimately through self-reflection and community building.

This study yields some interesting implications for social work. One implication is the importance of supporting racialized women in their need for community building. Study findings detailed the detrimental impacts of pervasive whiteness on racialized women. With the goal of fostering racialized women's liberation and dignity, future studies should be conceptualized with a deliberate aim to involve multiracial black individuals in order to account for unique embodied experiences with gendered racialization. 


\section{APPENDIX A: Consent Form}

You are being invited to participate in a research study. Please read this consent form so that you understand what your participation will involve. Before you consent to participate, please ask any questions to be sure you understand what your participation will involve.

Exploring Complexities: Multiracial Black Women - Racism, Sexism and Resistance INVESTIGATORS: This research study is being conducted by Shala Symonds and supervised by Dr. Gordon Pon, from the School of Social Work at Ryerson University. If you have any questions or concerns about the research, please feel free to contact Shala at shala.symonds@ryerson.ca or (647) 6318620.

\section{INCLUSION CRITERIA:}

You may be considered for this study if you:

- Self identify with being multiracial, biracial, and/or mixed-race

Have one parent that identifies as black (race/ethnicity)

- Self-identify as a woman/ female/ femme, And

- Have experienced racism and/or sexism, And/ Or

- Have an opinion about racism and/or sexism that they would like to share.

\section{PURPOSE OF THE STUDY:}

The purpose of this study is to explore how multiracial black women experience, understand, and resist racism and sexism. Two to four participants are being recruited for the study.

In order to be considered for this study (as detailed above) you should: a) self-identify with being multiracial, biracial, and/or mixed-race, b) have one black parent (race/ethnicity), c) self-identify as a woman/ female/ femme, and d) have experienced racism and/or sexism, and/or, have an opinion about racism/ sexism that you would like to share.

This research study is being conducted as a requirement of the Masters of Social Work degree program at Ryerson University. The findings will result in a major research paper (MRP) submitted to the University in August 2017.

\section{What you Will Be Asked to Do/ What Participation MeanS:}

If you volunteer to participate in this study, you will be asked to do the following things:

- Come to a one to two hour interview with the researcher in a privately booked room in the Ryerson campus library or at destination that you and the researcher agree upon that provides aural and visual privacy OR participate in the interview over the phone; make a decision (with the researcher) on a convenient date/time for the interview to take place

- The interview will be audio-recorded (if is not conducted electronically over the phone)

- Talk about your experiences with racism/ sexism

- Talk about how you understand those experiences

- Talk about the ways in which you challenge or resist racism and/or sexism

- Some sample interview questions might include:

A) Describe a time that you experienced racism.

- B) How would you describe your racial/ ethnic identity/ your ethnicity?

$\circ \quad$ C) How do you respond to racist statements, comments, slurs, etc. from others?

- The researcher will require your name, age, race/ethnicity, phone number, email address, and the town/ city, province, country that you grew up in. All personal information will be destroyed after the study is complete, and you will be given a pseudonym (fake name) in the Major Research Paper.

- The findings will be made available to you by email before the Major Research Paper is submitted.

- You can withdraw from the study at any time without repercussion. You may also skip questions and/or decide to remove their interview all together from the research study.

\section{Potential Benefits}


I cannot guarantee that you will experience any of theses benefits, however, I am confident that the potential benefits to participating in this study are:

1) To have your voice contribute to a gap in literature and research on multi-racial black women's experiences with racism and sexism.

2) To contribute to a growing body of knowledge that is missing your narrative, lived experiences, and expertise on multi-racial black women's experiences

3) To talk openly about the complexity of race, sex, identity, and resistance in a 'safe space'

\section{What are the Potential Risks to you as a Participant}

Psychological

1) Emotional and/or psychological distress in recalling experiences with racism/ sexism

Personal Identity Being Revealed

(e.g. participant being identified either directly or inadvertently)

2) There may be a risk of personal identity being revealed, given that you are known to me, you Dual-role may know of/recognize other participants in the final research paper, and they the same for you

(e.g. related to already-existing relationships between researcher and participants)

3) Confusion regarding what part of the interview is personal/informal and what part is research/ formal

4) Risk of disclosing more personal information than intended, given the rapport and trust from the personal relationship

5) Feelings of obligation to share more information/ details than you wish in order to support the researcher's work

In order to mitigate these risks, you are welcomed to skip questions if you feel uncomfortable, or stop your participation either temporarily or permanently. You will be provided with local, Toronto-based counselling resources prior to the interview. In respecting confidentiality, I will keep your name private and unknown to other participants. I will also select participants who do not know each other personally/ directly. I will also review the consent form with you prior to conducting the interview in order to promote your understanding of the risks involved, including a thorough understanding of the voluntary nature of your participation. The interview transcripts will also be emailed to you prior to my use of them in the final paper. In doing so, you can evaluate/ make changes to your interview transcription. Finally, I will use pseudonyms (fake names) in the final paper.

\section{Confidentiality:}

- Confidentiality of records identifying you will be maintained through password-protected devices (computer/ audio recorder).

- A pseudonym will be assigned to you in the Major Research Paper.

- Your personal information will be kept until a final draft of the major research paper is created, expected August 2017.

- Disclosure of information to an outside party will only be required if you disclose a desire to harm yourself or someone else; the outside party is determined by the research supervisor, Dr. Gordon Pon.

- You are to be audio-recorded. You have the right to review/edit the transcription of their recording before the transcription is used in the final paper. The recording will be stored on a password-protected device, of which solely the primary investigator has access. Solely the primary researcher (myself) will have access to the raw and transcribed recordings. Recordings will be destroyed after the transcription process, an estimated two - three weeks post interview.

\section{Voluntary Participation and Withdrawal:}

For participants who have a pre-existing relationship with me, I wish to emphasize that participation in this study is completely voluntary, and non-participation will have no adverse impact on pre-existing relationships. Due to the voluntary nature of this study, you may stop participating at any time throughout the study with zero potential for reprisal from the researcher, supervisor, and/or academic institution. If any question(s) makes you feel uncomfortable, you can skip that/those question(s). If you choose to stop 
participating, you may also choose to not have your data included in the study. Your choice of whether or not to participate will not influence your future relations with Ryerson University or the investigators involved in the research, Shala Symonds and Dr. Gordon Pon.

Questions about the Study: If you have any questions about the research now, please ask. If you have questions later about the research, you may contact:

- Shala Symonds (primary investigator) Masters of Social Work student, Ryerson Universityshala.symonds@ryerson.ca

- Dr. Gordon Pon, Professor at Ryerson University, School of Social Work - g2pon@ryerson.ca This study has been reviewed by the Ryerson University Research Ethics Board.

If you have questions regarding your rights as a participant in this study please contact:

Research Ethics Board

c/o Office of the Vice President, Research and Innovation

Ryerson University

350 Victoria Street

Toronto, ON M5B 2K3

416-979-5042

rebchair@ryerson.ca

\section{CONFIRMATION OF AGREEMENT:}

Your signature below indicates that you have read the information in this agreement and have had a chance to ask any questions you have about the study. Your signature also indicates that you agree to participate in the study and have been told that you can change your mind and withdraw your consent to participate at any time. You have been given a copy of this agreement.

You have been told that by signing this consent agreement you are not giving up any of your legal rights. 


\section{APPENDIX B: Interview Guide}

\section{Major Research Question: How do multiracial black women experience, understand, and resist racism and sexism? \\ Disclaimer/ Trigger-warning:}

Due to the sensitive nature of the topics that we'll be discussing, I have provided a list of local (Torontobased) counseling resources for you. I also want to remind you of the voluntary nature of participating in this study. You are welcome to skip questions, and/or stop participating at anytime. We will also review the consent form together prior to the commencement of the interview questions below.

Demographic Data

1. What is your name/ email/ telephone?

2. What is your age?

3. Where did you grow up (town/ city, province, country)?

4. How would you describe your ethnicity? Identity

1. How do you self-identify racially? / How would you describe your our race?

How would you describe your ethnicity?

2. How do you feel about the terms 'mixed'/ biracial/ multiracial, etc. in relation to yourself (as it applies to your personal sense of self).

3. Can you tell me more about why/ how you've come to identify the way you currently do?

Have there been certain life experiences that have contributed to shaping your racial/ ethnic identity?

4. How does being 'black' relate to your racial/ethnic identity?

Privilege/ Disadvantage

1. Do you believe that you experience some privileges in society for being multi-racial rather than monoracial (i.e. full black, full brown, full white, etc.)?

2. Do you believe that you experience some disadvantages in society for being multi-racial rather 'monoracial'?

3. How are your 'privileges' and/or 'disadvantages' related to your experience as a woman (female, femme, etc.)?

Racism

1. Can you tell me about a time that you experienced racism (describe a time that you experienced racism)?

What kind(s) of prejudice do you think was/were operating in that moment?

2. Do you think that being 'mixed'/ biracial/ multi-racial, etc. makes you subject to more or less racism in comparison to others (mono-racial individuals and/or those who appear to be mono-racial)?

Do you think history contributes to this? If so, can you elaborate/ explain?

Overt/ Blatant Racism

1. Have you ever been called the N-word?

How did that make you feel?

3. How do you respond to racist statements, comments, slurs, etc. from others?

2. Have you ever been assaulted or overtly harmed in a way that you felt was racially motivated?

Micro-aggressions

What was that experience like for you mentally/ emotionally?

1. Do you get asked: 'Where are you from?' often?

- If yes, how does that make you feel?

- If yes, why do you think people ask you that?

- What do you think of the term 'exotic'? Would you consider yourself 'exotic'?

2. Do people often compliment, insult, or comment on your skin tone?

- If yes, why do you think they do that?

- How does it make you feel?

3. Do people often inquiry about your hair? 
4. Do they touch your hair without asking?

- If yes, how does it make you feel?

- If yes, how do you handle those situations?

- If yes, what is the racial/ethnic background of those who inquire about and/or touch your hair?

Sexism

1. Can you tell me about a time that you experienced sexism/ patriarchy/misogyny, etc.?

2. Can you describe some of the pressures that you believe are associated with being a woman?

3. Do you think that being multi-racial/black provides you with unique experiences of sexism?

- Are these experiences that you think white women or other racialized women may not experience?

Internalized Oppression

1. Are there any racist messages that you believe you have internalized?

2. Are there any sexist ideas that you believe you have internalized?

Resistance

1. Can you tell me about how you counter your experiences with racism?

2. Can you tell me about how you counter your experiences with sexism? 
Hi,

\section{APPENDIX C: Recruitment Script}

As you probably know, my name is Shala and I'm currently completing a Graduate program at Ryerson University. As a requirement of my Master of Social Work degree, I'm conducting a study that seeks to explore how multiracial black women experience, understand, and resist racism and sexism. Professor, Dr. Gordon Pon, is supervising my research.

In order to be considered for this study, interested potential participants should:

a) Self-identify with being multiracial, biracial, and/or mixed-race,

b) Have one parent that identifies as black (race/ethnicity)

c) Self-identify as a woman/ female/ femme, and

d) Have experienced racism and/or sexism/ have an opinion about racism and/or sexism that they would like to share.

If you are interested in participating in this study you will be required to participate in a one to two hour interview, with myself, which will take place in person or over the phone. The identities of the participants in this study will remain confidential and pseudonyms (fake names) will be used in the final research report. For participants who have a pre-existing relationship with me, I wish to emphasize that participation in this study is completely voluntary and non-participation will have no adverse impact on pre-existing relationships. If you are interested in participating in this study, you will also be required to sign an informed consent form prior to the commencement of the interview.

If you are interested in being a participant in this study, please contact me by phone call, text, or email. If I am unable to answer your call, please leave me a detailed voice-message or send me a text, and I will return your call as soon as I'm able.

What Participation Means (What you'll be asked to do)

If you volunteer to participate in this study, you will be asked to do the following things:

- Come to a one to two hour interview with the researcher (myself) at a privately booked room at the Ryerson University library, or at destination that you and I agree upon (that provides visual and aural privacy) Or if the interview takes place over the phone, decide on a convenient date and time.

- Talk about your experiences with racism and sexism

- Talk about how you understand those experiences

- Talk about the ways in which you challenge and/or resist racism and sexism

- Some sample interview questions might include:

a) Describe a time that you experienced racism.

b) Describe your racial or ethnic identity.

c) How do you think your racial/ethnic identity relates to your experiences with racism?

d) How do you respond to racist statements, comments, slurs, etc. from others?

- I will require your name, age, racial/ethnic identity, phone number, email address, and the town or city/ province you grew up in. All personal information will be destroyed after the study is complete, and participants will be given pseudonyms in the Major Research Paper (MRP).

- The findings will be made available to the participants by email, mail, or delivered in person, before the Major Research Paper is submitted.

- You can withdraw from the study at any time without repercussion. You may also skip questions and/or decide to remove their interview all together from the research study.

- I will also provide you with a list of local (Toronto-based) counselling resources.

It would be great to work with you in this capacity. Thanks for your consideration and if you are interested in participating in this study please contact me at (647) 631-8620 or at shala.symonds@ryerson.ca

Shala Nakaw Symonds

MSW Candidate, Ryerson University 


\section{REFERENCE LIST}

Bailey, T. M., Chung, Y. B, Williams, W. S., Singh, A. A., \& Terrell, H. K. (2011). Development and validation of the internalized racial oppression scale for Black individuals. Journal of Counseling Psychology, 58(4), 481-493. DOI: 10.1037/a0023585

Baskin, C. (2006). Aboriginal worldviews as challenges and possibilities in social work education. Critical Social Work, 7(2), [online journal]. Retrieved January 8, 2009, from http://www.criticalsocialwork.com/units/socialwork/critical.nsf/982f0e5f06b5c9a285256d6e006c ff78/536be566187cf89285257277002adb1d?OpenDocument

Benjamin, A. (2003). The dialectics of anti-Black racism (Doctoral dissertation). Ontario Institute for Studies in Education of the University of Toronto, Toronto, ON.

Bettez, S. C. (2010). Mixed-race women and epistemologies of belonging. Frontiers: A Journal of Women Studies, 31(1), 142-165. http://doi.org/10.1353/fro.0.0074

Calmore, J. O. (1995). Critical race theory, Archie Shepp, and fire music: Securing an authentic intellectual life in a multicultural world. In K. Crenshaw, N. Gotanda, G. Peller, \& K. Thomas (Eds.), Critical race theory: The key writings that formed the movement (pp. 315-328). New

York, NY:

The New Press.

Chase, S. (2003). Learning to listen: Narrative principles in a qualitative methods research course.

Josselson, R., Lieblich, A., \& McAdams, D. P. (Eds.), Up close and personal: The teaching and learning of narrative research (79-99). Washington, DC: American Psychological Association.

Cho, S., Crenshaw, K. W., \& McCall, L. (2013). Toward a field of intersectionality studies: Theory, applications, and

praxis. Journal of Women in Culture and Society, 38(4), 785-809.

Clarke, J. (2012). Beyond child protection: Afro-Caribbean service users of child welfare. Journal of Progressive Human Services, 23(3), 223-57.

Coleman, V. H., \& Carter, M. M. (2007). Biracial self-identification: Impact on trait anxiety, social 
anxiety, and depression. Identity: An International Journal of Theory and Research, 7(2), 103 114.

Crenshaw, K. (1993). Mapping the margins: Intersectionality, identity politics, and violence against women of color. Stanford Law Review, 43(6), 1241-1299. Retrieved from http://www.jstor.org/stable/1229039

Crenshaw, K. W. (1991). Mapping the margins: Intersectionality, identity politics, and violence against women of color. In K. Crenshaw, N. Gotanda, G. Peller, \& K. Thomas (Eds.), Critical race theory: The key writings that formed the movement (pp. 357-383). New York, NY: The New Press.

Calmore, J. O. (1995). Critical race theory, Archie Shepp, and fire music: Securing an authentic intellectual life in a multicultural world. In K. Crenshaw, N. Gotanda, G. Peller, \& K. Thomas (Eds.), Critical race theory: The key writings that formed the movement (pp. 315-328). New

York, NY: The New Press.

Creswell, J. W. (2013). Qualitative inquiry \& research design: Choosing among five approaches ( $3^{\text {rd }}$ ed.). Los Angeles: SAGE

Dei, G. J. S. (1996). Anti-racism education: Theory and practice. Halifax, NS: Fernwood Publishers. Donovan, R., \& Williams, M. (2002). Living at the intersection: The effects of racism and sexism on black rape survivors. (Shala list the editors of this book and publisher and city) Violence in the Lives of Black Women, 95-105.

Evans-Winters, E., \& Esposito, J. (2010). Other people's daughters: Critical race feminism in black girls' education. Educational Foundations, 24(1-2), 11-24.

Exotic (2017). Dictionary.com. Retrieved from http://www.dictionary.com/browse/exotic?s=t

Fanon, F. (2008). Black skin White masks. (R. Philcox, Trans.). New York, NY: Grove Press. (Original work published 1952)

Forsyth, J. \& Carter, R., T. (2012). The relationship between racial identity status attitudes, racism-related coping, and mental health among Black Americans. Cultural Diversity and Ethnic Minority 
Psychology, 18(2), 128-140. DOI: 10.1037/a0027660

Giroux, H. A. (2003). Spectacles of race and pedagogies of denial: Anti-Black racist pedagogy under the reign of neoliberalism. Communication Education, 52(3/4), 191-211.

DOI:10.1080/0363452032000156190

Haritaworn, J. (2007). Beautiful beasts: Ambivalence and distinction in the gender identity negotiations of multiracialized women of Thai descent. Women's Studies International Forum, 30, 391-403.

Heidegger, M. (1977). The question concerning technology and other essays (W. Lovitt, Trans) New York: Harper and Row.

Henry, F., \& Tator, C. (2010). The colour of democracy: Racism in Canadian society (4 ${ }^{\text {th }}$ ed.). Toronto, ON: Nelson Education Ltd.

hooks, b. (1981). Ain't I a woman: Black women and feminism. Boston, MA: South End Press.

hooks, b. (1992). Black looks: Race and representation. Boston, MA: South End Press.

James, C. E., Este, D., Bernard, W. T., Benjamin, A., Lloyd, B., \& Turner, T. (2010). Race and well being: The lives, hopes, and activism of African Canadians. Halifax, NS: Fernwood Publishing.

Kohli, R. (2014). Unpacking internalized racism: Teachers of color striving for racially just classrooms. Race ethnicity and education, 17(3), 367-387. http://dx.doi.org/10.1080/13613324.2013.832935

Lowe, L. (1996). Immigrant acts: On Asian American cultural politics. Durham, NC: Duke University Press.

Lusk, E. M., Taylor, M. J., Nanney, J. T., \& Austin, C. C. (2010). Biracial identity and its relation to self-esteem and depression in mixed Black /White biracial individuals. Journal of Ethnic and Cultural Diversity in Social Work, 19:109-126. http://doi.org/10.1080/15313201003771783

Moustakas, C. (1994). Phenomenological research methods. Thousand Oaks, CA: SAGE. Doi: $10.4135 / 9781412995658$

Pon, G. (2009). Cultural competency as new racism: An ontology of forgetting. Journal of Progressive Human Services, 20(1), 59-71.

Pon, G., Gosine, K., \& Phillips, D. (2011). Immediate response: Addressing anti-Native and anti-Black 
racism in child welfare. International Journal of Child, Youth and Family, 2(3/4), 385-409.

Pyke, K. D. (2010). What is internalized racial oppression and why don't we study it? Acknowledging racism's hidden injuries. Sociological Perspectives, 53(4) 551-572. http://doi.org/10.1525/sop.2010.53.4.551.552

Razack, S., Smith, M., \& Thobani, S. (2010). Introduction. In S. Razack. M. Smith, \& S. Thobani (Eds.), States of race: Critical race feminism for the 21st century (pp. 1-19). Toronto, ON: Canadian Scholars' Press.

Rockquemore, K. A., \& Laszloffy, T. A. (2003). Multiple realities: A relational narrative approach in therapy with Black-White mixed-race clients. Family Relations: Journal of Applied Family \& Child Studies, 52, 119-128.

Root, M. (2004). From exotic to a dime a dozen. Women \& Therapy, 27(1), 19-31. http://doi.org/10.1300/J015v27n01_02

Siddiqui, S. (2011). Critical social work with mixed-race individuals: Implications for anti-racist and anti-oppressive practice. Canadian Social Work Review, 28(2), 255 - 272.

Szymanski, D., M. \& Gupta, A. (2009). Examining the relationship between multiple internalized oppressions and African American lesbian, gay, bisexual, and questioning persons' self-esteem and psychological distress. Journal of Counseling Psychology, 56(1), 110-118.

DOI:10.1037//a0012981

Szymanski, D., M. \& Stewart, D., N. (2010). Racism and sexism as correlates of African American women's psychological distress. Sex Roles 63: 226-238. DOI 10.1007/s11199-010-9788-0

Tate, S. (2007). Black beauty: Shade, hair and anti-racist aesthetics. Ethnic and Racial Studies, 30(2), 300-319.DOI: 10.1080/01419870601143992

Thobani, S. (2007). Exalted subjects: Studies in the making of race and nation in Canada. Toronto, ON: University of Toronto Press

van Manen, M. (1990). Researching lived experience: Human science for an action sensitive pedagogy. Albany: State University of New York Press. 
Watts-Jones, D. (2002). Healing internalized racism: The role of a within-group sanctuary among people of African descent. Family Process, 41(4), 591-601.

http://doi.org/10.1111/j.1545-5300.2002.00591.x

Wing, A. K. (Eds.). (2003). Critical race feminism: A reader. New York, NY: New York University

Press.

Wing Sue, D., Capodilupo, C. M., Torino, G. C., Bucceri, J. M., Holder, A. M. B., Nadal, K. L., Esquilin, M. (2007). Racial microaggressions in everyday life: Implications for clinical practice. American Psychologist, 62(4), 271- 286. DOI:10.1037/003-066X.62.4.271 